\title{
頸椎後縦靱帯骨化症に対する前方除圧術
}

\author{
阿部弘・伊藤 輝史・岩崎 喜信 -中川 端午 \\ 北岡 憲一・都留美都雄・小岩 光行* ・斉藤 久求*
}

\section{Anterior Decompression for Ossification of the Posterior Longitudinal Ligament of the Cervical Spine}

\author{
Hiroshi Abe, Terufumi Ito, Yoshinobu Iwasaki, Tango Nakagawa, \\ Kenichi Kitaoka, Mitsuo Tsuru, Mitsuyuki Korwa* and Hisatoshi Sarto* \\ Department of Neurosurgery, University of Hokkaido, Sapporo 060 \\ * Department of Neurosurgery, Kushiro Rosai Hospital
}

\begin{abstract}
Summary
The operative procedurcs for ossification of the posterior longitudinal ligament (OPLL) of the cervical spine are mainly divided into two types, i.e., the posterior approach and the anterior approach. We conducted surgical treatment on about fifty cases of OPLL by the postcrior approach until 1977. The resul ts were mostly satisfactory for the spinal cord signs, but sometimes we could not improve the radicular signs. In addition, since ossification of the ligament continued to progress, we could do nothing about aggravation arising several years later. Therefore, we have tried a new and radical method which is called anterior decompression since 1978. The central part of the vertebral body and the ossified area of the posterior longitudinal ligament are removed and the defect is filled with a bonegraft. Twelve cases of OPLL were operated on in our department in the last two years. Surgical techniques, operative results and indications are discussed.

A longitudinal groove of sufficient length and approximately $1.2-1.5 \mathrm{~cm}$ in width is made in the center of the vertebral bodies using a rongcur and an air-drill. When the posterior surface of the vertebral bodies is approached, the procedure should be performed with extra caution under a surgical microscope. The normal part of the dura must be exposed first, and the ossified ligament is carefully removed with a micro-rongeur. When the ossified ligament adheres tightly to the dura, the dura involved must be extirpated. The posterior part of the body should be cut widely so that the lateral part of the ossified ligament can be removed easily. $A$ bone-graft taken from the iliac crest is made to fit the graft bed.

The operative results were excellent even though the lateral parts of the ossified ligament were not removed completely in three cases and fracture of the grafted bone occurred in two cases. Marked improvements of radicular and spinal cord signs were seen in all twelve cases. There were no cases in which signs of aggravation of the neurological symptoms appeared after the operation. Three bodies fused in one case, four bodies in nine cases, and five bodies in two cases. The highest level of the fusion was $C_{2}$ and the lowest level was $T_{1}$. When the percent narrowing of the cervical spinal canal was over fifty percent and remarkable cord signs were present, there was a tendency for the improvement of the cord signs to be delayed. When there is a gait disturbance, the operation should be performed without hesitation. Theoretically, it is considered that any ossification of the ligament can be removed by the anterior approach as long as the number of vertebral bodies involved does not exceed five $\left(\mathrm{C}_{3}-\mathrm{C}_{7}\right)$. Spinal CT scans were valuable and essential to obtain more detailed information about the stenotic spinal canal and
\end{abstract}

\footnotetext{
北海道大学膇神経外科

*釗路学災病院畄神経外科

[連絡先：干060 柇幌市北区北15条西 7 丁目，北海道大学脳神経外科，阿部弘]

1980年 3 月 5 日 受稿
} 
shape of the ossified ligament.

Key words: spinal canal, ossification, spinal GT, anterior decompression, posterior longitudinal ligament

\section{I はじめに}

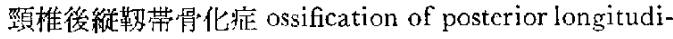
nal ligament of cervical spine (以下 OPLL と称与) に対 する外科的治療沬，往来上り主として laminectomyに上

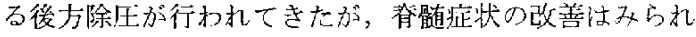
ても，神経根症状の改善は必ずしも常䍀足才心きもの とはいえなかった。さらに鞄带の骨化は依然として進行 するので，後滁压によって一時的に症状の軽快るれて も，数年後仙再び悪化してくる，そこで著者らは上り 根治的な方法として，前方上り到澾し，椎体，椎閶板上 ともに後雅䩚带骨化巣索完全に摘出する前方除圧術を 1978年より試み，12例の経験民得た。経果は良好で全例

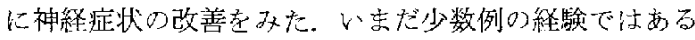
が主として手術術式执よび適応について検封した結果を 報告する。

\section{II対象および方法}

1978年 1 月より1979年8月までに，北海道大学訤神経

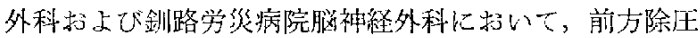
術が施行された12例の OPLL 症例在検詰した。

頸椎断層撮影（矢状断）で得られた骨化像に上って会 椎管闹後径がもっとも狭められた椎体レぶルに执いて，

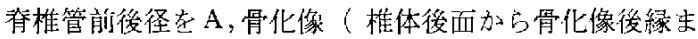

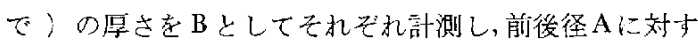

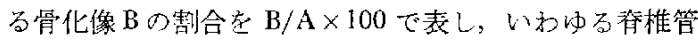
前後径狭小率とした（Fig，1)。

前方除圧術り行われた12例り手術成績, 脊椎管狭小率 と症状の関係，手術手技上の問題点などについて檢討存 如文た。

手術片法は Fig. 2 から Fig. 4 に示すごとくである。 まず air-drill 老用いて椎体正中部に必要な長さに幅 $1.2 \sim 1.5 \mathrm{~cm}$ の溝をあ叶る(Fig. 2a).椎体後面に近くな ったら，顕微鏡下にて air-drill の先も小さな diamond

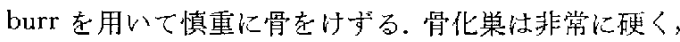
しばしば椎体後面との竟界は不明膫なので注意を要す る. 通常，健常な硬膜を露山乚，そこ上り骨化坚を $\mathrm{mi}$ cro-rongeur 用いて慎重に摘出寸る (Fig. 2b). 硬膜上 加らの出血は bipolar coagulator に上万凝国里たは gel一 form などで止血される。骨化巣の摘出沶，骨化坚方厚い
場合や硬い場合には必ずしも容㬎ではない，むっとも重

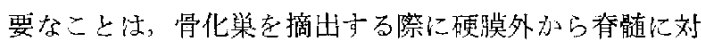

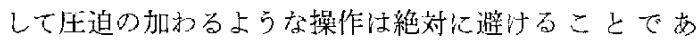
る。また骨化巣执硬膜し密着している埸合には硬膜ごと 摘出せ效ばならない，硬膜欠損部に対しては，その大き さにもよるが，gclform または乾燥硬膜で補充する。

椎体执上び骨化果は Fig. 3 に双るごとく，点線の部分 を摘出することになる。椎体を削るとき骨化紧の摘出老 容易にし，またとり残さないためにも椎体後面立前よ り兄幅広く削る必要がある，移植骨江腸骨から搡取する が，生理的弯曲在利用して骨皮質が前後にくるよらに挿 入寸る.上下の椎体に約 $1.5 \sim 2.0 \mathrm{~mm}$ ○媣さり瑇在作 り，澒椎を体軸方向に率引しながら移值骨を挿入し，移植 骨の逸脱を防ぐ

晹骨よりの移植骨は，削腸骨束束より $1.5 \mathrm{~cm}$ 後方より 必翣な長さに骨片を採取して，Fig. 4 のごとくBの部分 在使用する，Aの部分は腸骨陵の陌凹在防ぐをめ腸骨入

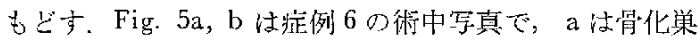

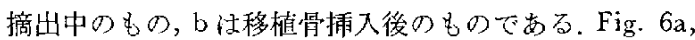
bは症例 9 の術中写真で， a は骬化紧摘出中， b 注移植 筒挿入後のものである。
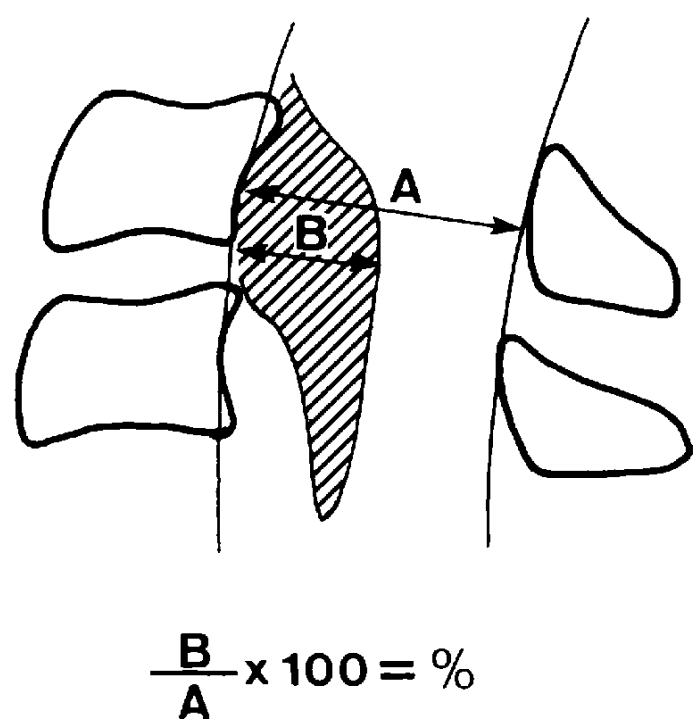

Fig, 1 Percent narrowing of the spinal canal (anterior-posterior diameter). 


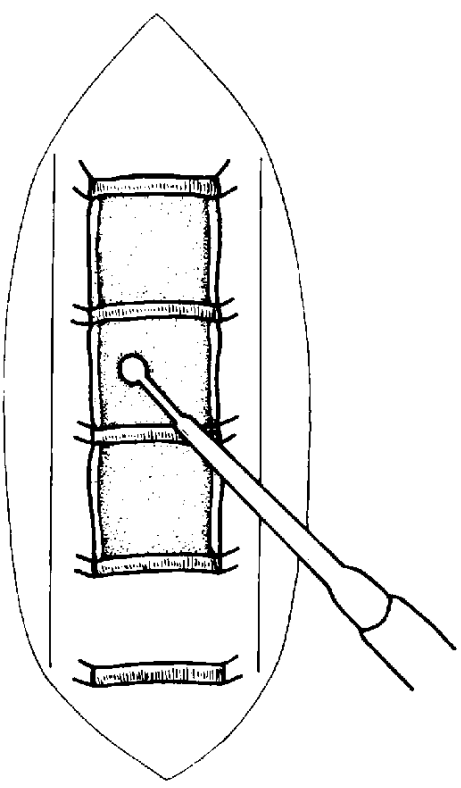

a

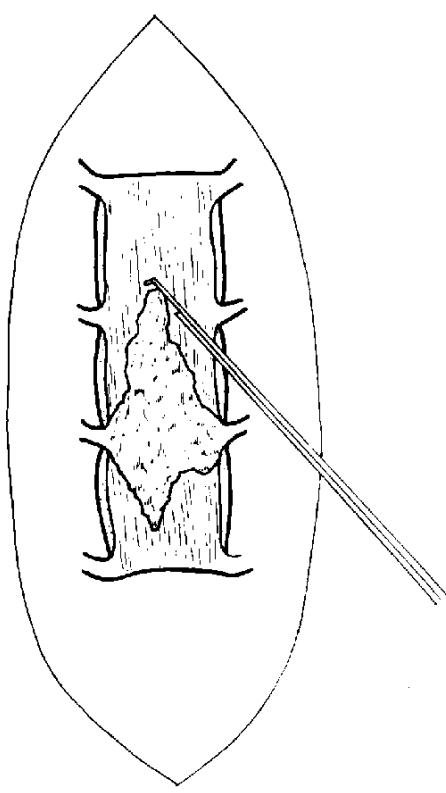

$\mathrm{b}$

Fig. 2a: Resection of the central part of the vertebral bodies b: Removal of ossificd ligament.

術後は約 4 6 週問ベッド上で卧床安静を保ち， 6 週 後から项椎カラーを装用して起立，歩行を開始させる。

\section{III症例および結果}

\section{1. 年令, 性, 部位 (Table 1)}

年命は39才から68才にわたり，平均51才であった。性 別で江男性10例，女性 2 例で圧倒的に男性江多加った。

骨化部位は上は $\mathrm{C}_{2}$ 下縁,下は $\mathrm{T}_{1}$ 上粶に及んでいた。 骨化巣の長さでは，1椎体レベルのるの1例，2椎体に

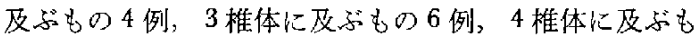

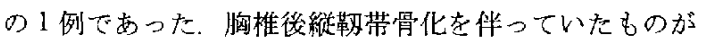
2 例あった。

\section{2. 鿖椎管狭小率と神経症状}

Table 1 は，いわ沙る脊椎管前後径狭小率の高いもの から順に並べた表である，㹟小率の高いものでは76\%に も達した。

神経症状は，神経根症状と沓䯣症状沅わけて検討 し た。一は症状なし，十は軽度障害あり，井は中等度障害 岕り，卅注高度障害ありを表す，狭小率50\%以上のもの は脊䯣症状の著明なものが多い傾向ではあったが，症例 3，症例 5 の上うにとれぞれ狭小率が $57 \% ， 53 \%$ と高い

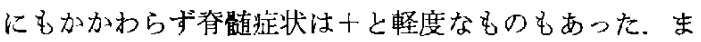

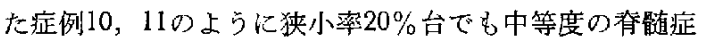
状がみられた。すなわち，春椎管狭小率と脊髄症状の程
度は必すしも平行するとはいえなかった，また骨化巣 に上って狭窄された実際の春椎管前後 径 absolute anterior-posterior diameter 青椎管狭小率とほほ同じ㑯向を 示し，脊䯚症状の程度と必ずしも平行しなかった。

一方神経根症状で汢，背椎管狭小率が50\%以上のもの に中等度に障害されていたものが多かった。

\section{3. 症 例}

次症例を 4 例供筧する。

[症例 6]47才，男性。

1 年半前より両手指のシビレ感, 兩下肢のつっぱりと シビレ感を覚え, 次第に増恵して来院した，神経学的に 㹥両下肢の腱反射圥進, バビンスキー反射陽性, 足閒代

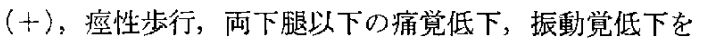
認めた。頸椎断層撮影にて $\mathrm{C}_{3}$ から $\mathrm{C}_{5}$ までの後縌勒帯 骨化像を認めた (Fig. 7a).春椎管狭小率 た. Manometric Queckenstedt's test で不完全ブロック を認め, myodil myelographyで骨化栄による著明な陰影 欠損を認め，髄液蛋白は $46 \mathrm{mg} / \mathrm{d} l$ と轻度上昇してい た。 そこで昭和53年 9 月29 日，先ず $\mathrm{C}_{2}$ から $\mathrm{C}_{6}$ までの laminectomy を行い，ついで10月11日前方到達法により 骨化巣老摘出し， $\mathrm{C}_{2}$ 加ら $\mathrm{C}_{5}$ までの前方固定を行った. 街後, 雨手指の知覚障害, 両下肢の spasticity は急速に 軽快し, 術後 1 年 3 力月目の現在, わずか纪下肢腱反射 光進を残すのみである。Fig. 7b は術後12力月目のむの 

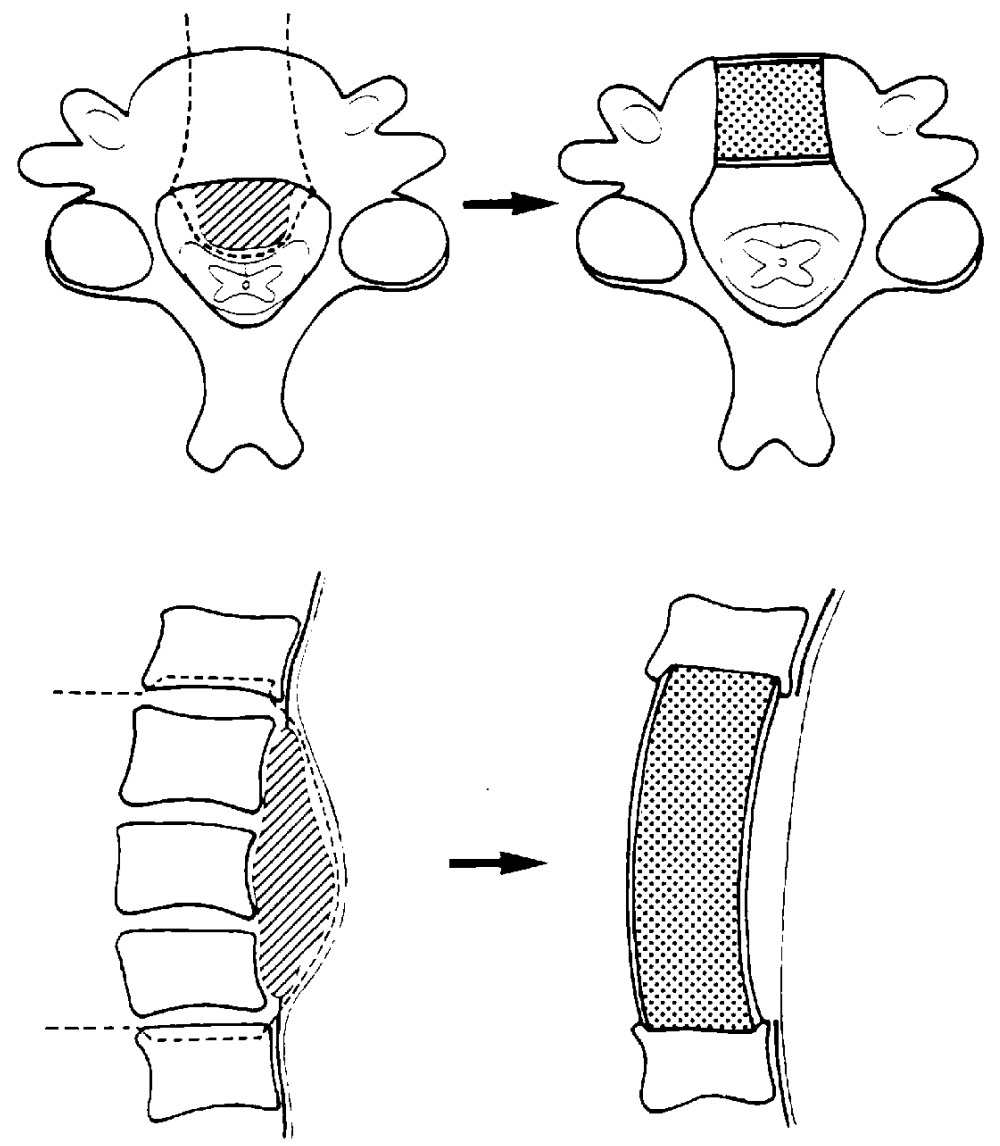

Fig. 3 Removal of ossified ligament and vertebral bodies. Anterior body fusion with iliac bone.

で骨化巣江消失し，移植骨注よく固定されている，盛前 ・郝後の spinal CT スキャンをみると, Fig. 8a, b のご とくで，骨化巣は完全汇消失している.

[症例 4] 49才, 男性.

10力月前上り右下肢の脱力が現われ，やがて右上肢の シビレ感，右手の巧繳障害も出現し，昭和54年 2 月13口 北海道大学脑神経外科一入院した，神释学的には右に強 い両上下肢の筋力低下，腱反射圥進，両側バビンスキー 反射陽性, 涇性歩行, 躬幹・雨下肢の振動覚低下゙などを

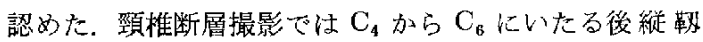
带骨化を認め扎 (Fig. 9a).春椎管狭小率は53\%であっ た。同作 3 月 15 日前方到達法により骨化巣摘出し， $C_{3}$ から $\mathrm{C}_{6}$ までの前方固定を行った(Fig. 9b)。術後10力月 目の現在，両下肢の腱反射充進を残すのみである。

[症例 3$] 48$ 才, 男性.

4 力月前に車を運転中に追突され，以後右手指のシビレ 感と頸部の運動に伴ら右上肢の将痛が出現した．昭和53
年12月15日北海道大学媨神経外科入入院した. 神経学的 には両手指，右上肢の筋力低下，両下肢の腱反射六進， 両手・両下肢の知営障害を認めた。顷椎断層撮影では $\mathrm{C}_{\mathbf{4}}$ から $C_{6}$ にいたる後縦勒带の骨化像を認めた（Fig. $10 a)$ ，唪椎管狭小率は57\%であった。昭和54年 1 月 16 日 前方到達法により骨化巣索摘出し， $\mathrm{C}_{3}$ から $\mathrm{C}_{7}$ まで固定 した (Fig. 10b)。術前・術後の spinal CT スキャンは Fig. 11a，bのごとくである. 術後, 両手の筋力低下拉よ び両手・両下肢の知覚障淎著しく改善した，術後12力 月自の現在, 神経学的に異常所見を誌めない.

[症例11]61才, 男性.

2 力月前に歩行中転倒し両上肢の脱力とシビレ感が出 現し，1力月後に步行障害が加わり漸次增悪してきた。 昭和54年 4 月 17 日北海道大学脳神経外科を受診した, 神 経学的汇両上肢の筋萎縮と笳力低下, 著明な㾏性歩行, 両下肢の腱反射六進, 右上下肢の痛覚鈍麻を認㱛た。頸 椎断層写真では， $\mathrm{C}_{5}$ から $\mathrm{C}_{7}$ にいたる後綎䩚帯の骨化像 

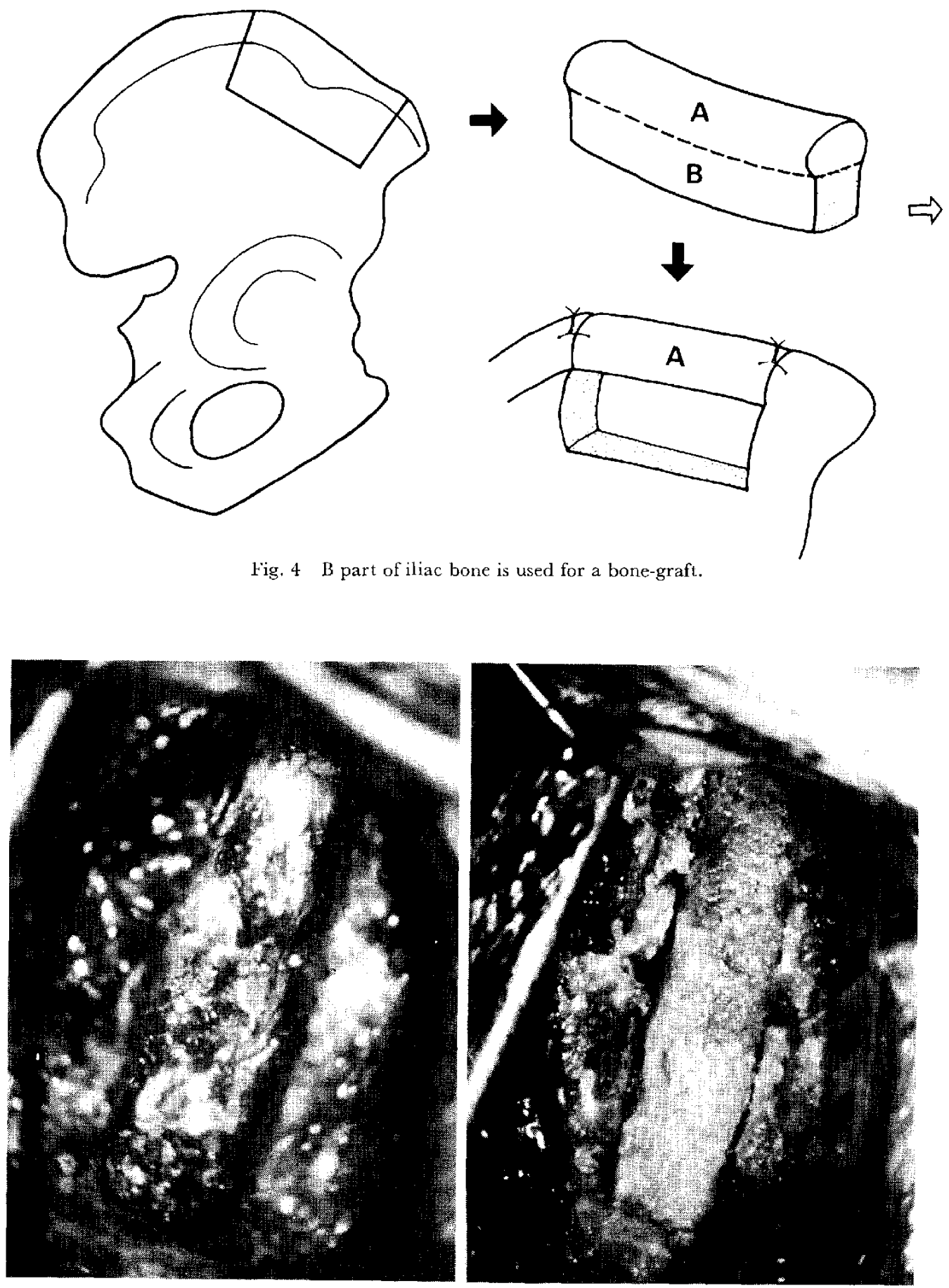

b

Fig. 5 Case 6

a: Ossified ligament at $\mathrm{C}_{3}-\mathrm{C}_{5}$.

$\mathrm{b}$ : Anterior body fusion. 


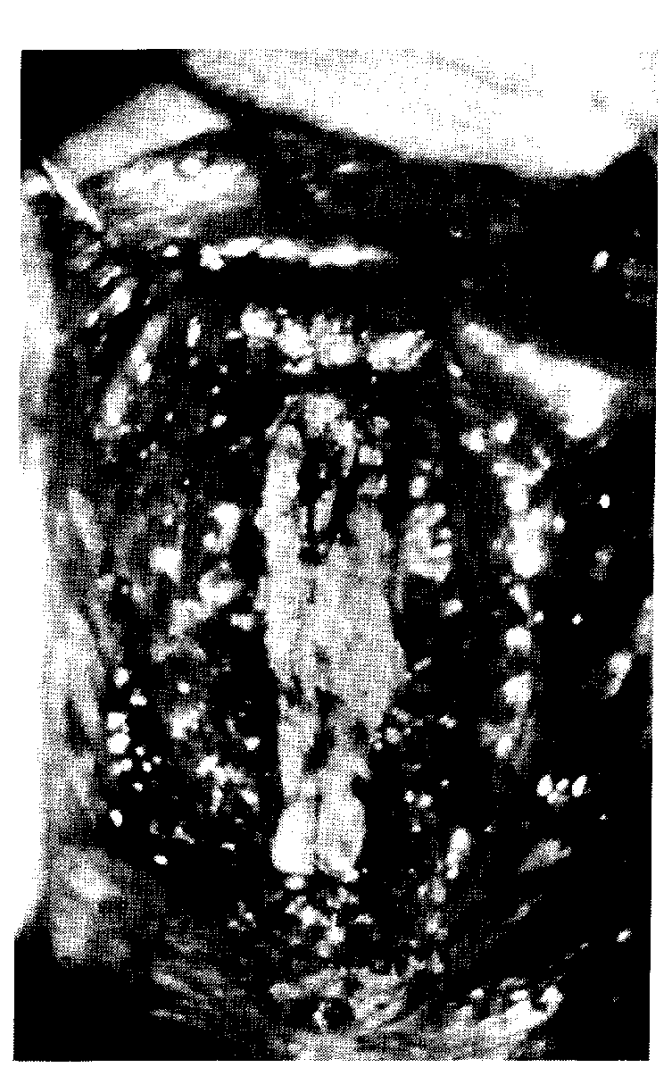

a

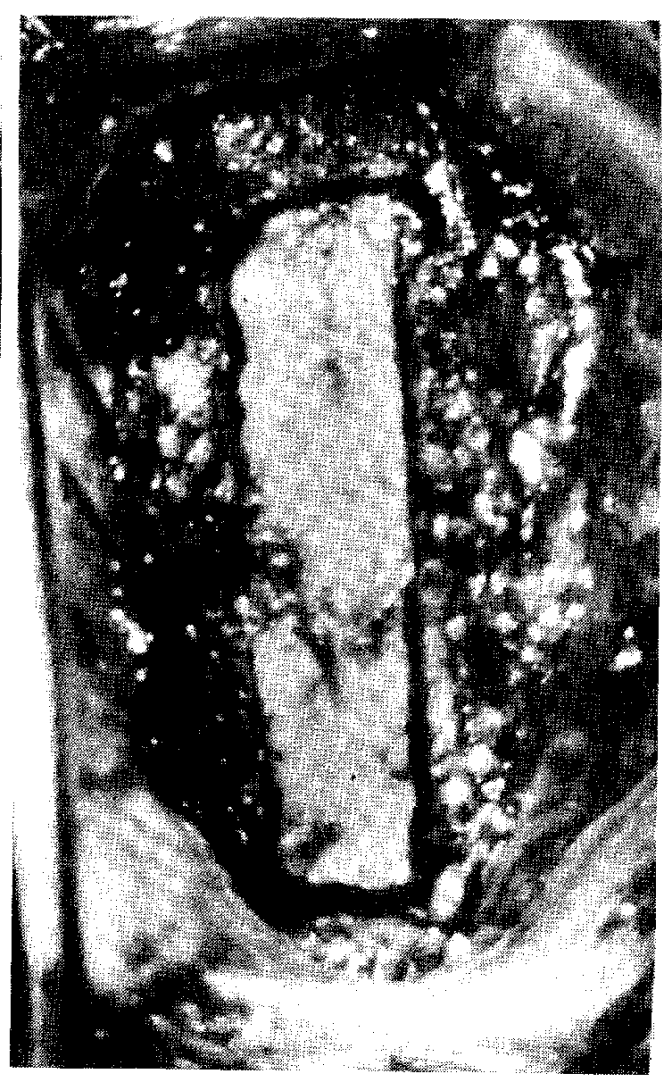

b

Fig. 6 Case 9

a: Ossified ligament at $\mathrm{C}_{5}-\mathrm{C}_{7}$.

b: Anterior body fusion.

Table 1 Cases of ossification of the posterior longitudinal ligament (OPLL) treatcd by anterior decompression and fusion.

\begin{tabular}{|c|c|c|c|c|c|c|c|c|}
\hline & Age & Sex & OPLL & $\begin{array}{l}\text { Neuro } \\
\text { Root }\end{array}$ & $\begin{array}{l}\text { al signs } \\
\text { Cord }\end{array}$ & $\begin{array}{c}\text { Percent } \\
\text { narrowing }\end{array}$ & $\begin{array}{c}\text { Absolute } A-P \\
\text { diameter }\end{array}$ & Fused levels \\
\hline 1 & 52 & $M$ & $\begin{array}{c}\mathrm{C}_{5}-\mathrm{C}_{7} \\
\mathrm{Th}_{8}-\mathrm{Th}_{10}\end{array}$ & $H$ & HH & $76 \%$ & $4 \mathrm{~mm}$ & $\begin{array}{c}\mathrm{C}_{1}-\mathrm{C}_{7} \\
\text { (Laminectomy) }\end{array}$ \\
\hline 2 & 52 & $\mathbf{F}$ & $\begin{array}{c}\mathrm{C}_{5}-\mathrm{C}_{6} \\
\mathrm{Th}_{1}-\mathrm{Th}_{2}\end{array}$ & + & H & 57 & 6 & $\underset{\text { (Lamincetomy) }}{\mathrm{C}_{1}-\mathrm{C}_{7}}$ \\
\hline 3 & 48 & M & $\mathrm{C}_{4}-\mathrm{C}_{5}$ & H & $\vdash$ & 57 & 6 & $\mathrm{C}_{3}-\mathrm{C}_{7}$ \\
\hline 4 & 49 & $\mathrm{M}$ & $\mathrm{C}_{1}-\mathrm{C}_{6}$ & H & H & 53 & 7 & $\mathrm{C}_{3}-\mathrm{C}_{6}$ \\
\hline 5 & 50 & $\mathbf{F}$ & $\mathrm{C}_{5}-\mathrm{C}_{6}$ & H & + & 53 & 7 & $\underset{\text { (Laminectomy) }}{\mathrm{C}_{1}-\mathrm{C}_{7}}$ \\
\hline 6 & 47 & $\mathbf{M}$ & $\mathrm{C}_{3}-\mathrm{C}_{5}$ & + & $H$ & 50 & 8 & $\begin{array}{c}\mathrm{C}_{2}-\mathrm{C}_{5} \\
\text { (Laminectomy) }\end{array}$ \\
\hline 7 & 68 & $\mathrm{M}$ & $\mathrm{C}_{6}-\mathrm{C}_{7}$ & H & H & 47 & 8 & $\mathrm{C}_{5}-\mathrm{Th}_{1}$ \\
\hline 8 & 39 & $\mathbf{M}$ & $\mathrm{C}_{3}-\mathrm{C}_{6}$ & + & \pm & $3 j$ & 11 & $\mathrm{C}_{2}-\mathrm{C}_{5}$ \\
\hline 9 & 41 & $\mathrm{M}$ & $\mathrm{C}_{5}-\mathrm{C}_{7}$ & + & $1^{-}$ & 33 & 10 & $\mathrm{C}_{5}-\mathbf{T h}_{\mathbf{1}}$ \\
\hline 10 & 57 & $\mathrm{M}$ & $\mathrm{C}_{5}-\mathrm{C}_{\mathrm{B}}$ & + & $H$ & 29 & 10 & $\mathrm{C}_{4}-\mathrm{C}_{7}$ \\
\hline 11 & 61 & $\mathbf{M}$ & $\mathrm{C}_{5}-\mathrm{C}_{7}$ & + & $H$ & 21 & Il & $\mathrm{C}_{1}-\mathrm{Th}_{1}$ \\
\hline 12 & 49 & $\mathbf{M}$ & $\mathrm{C}_{6}$ & \pm & + & 14 & 11 & $\mathrm{C}_{5}-\mathrm{Th}_{1}$ \\
\hline
\end{tabular}




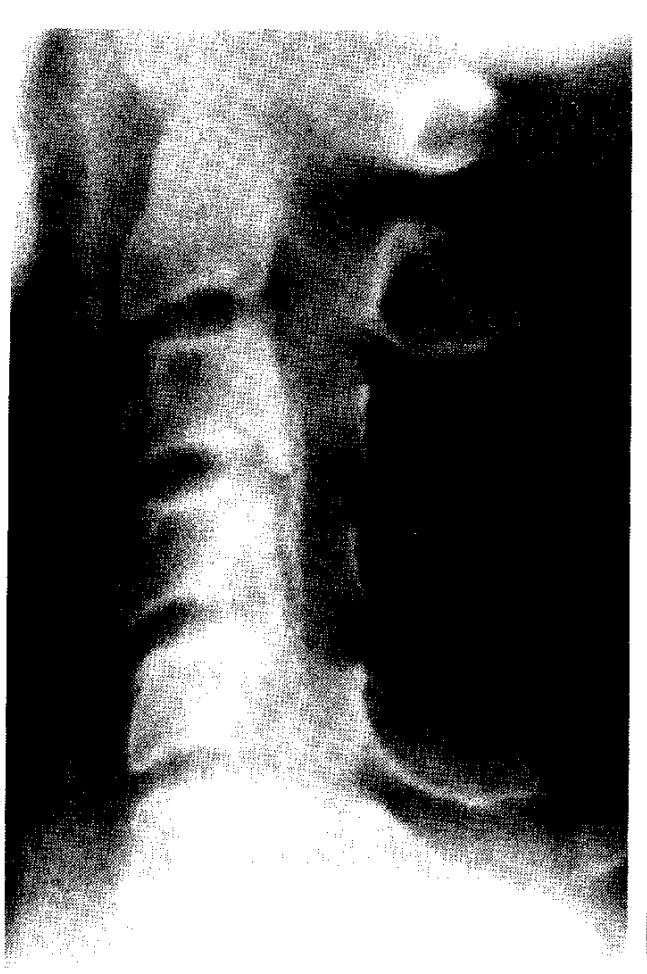

a

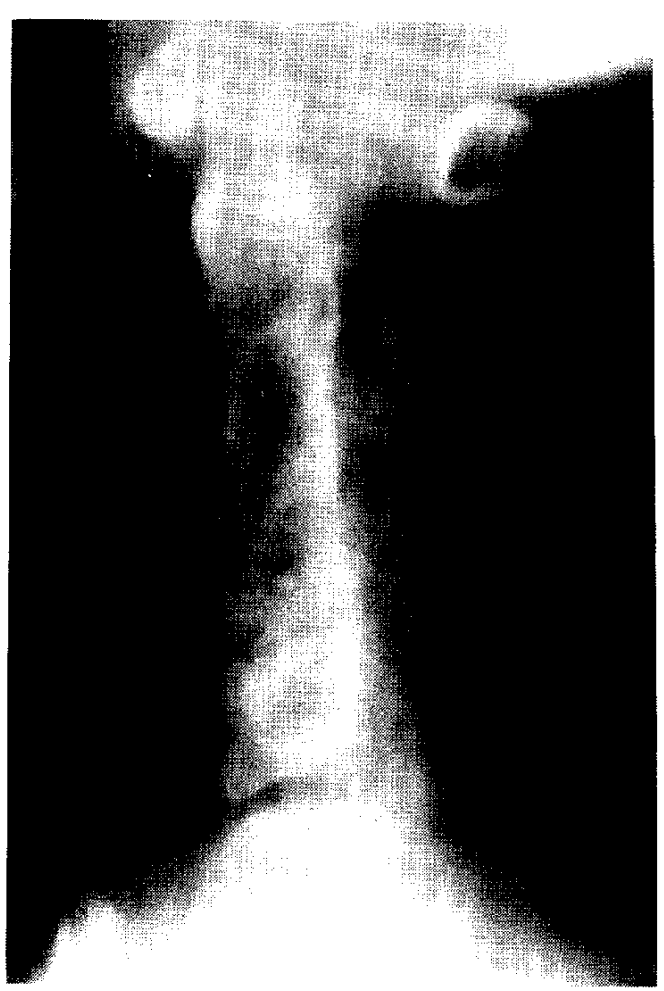

$\mathrm{b}$

Fig. 7 Case 6

a: Preoperative tomogram showing the ossified ligament at $\mathrm{C}_{3}-\mathrm{C}_{5}$

$\mathrm{b}$ : Ossified ligament was removed completely and anterior body fusion was carried out from $\mathrm{C}_{2}$ to $\mathrm{C}_{5}$. One year after the opcration.

を認め，春椎管狭小率は $21 \%$ あった. Manometric Queckenstedt's test では，高度のブロックを圭した，同 年 6 月 7 日前方到達法に上り骨化栄安摘出し， $\mathrm{C}_{4}$ 加ら $\mathrm{T}_{1}$ ま「の前方固定行った，術前・術後の spinal CT は Fig. 12a，b に示寸ごとくである. 術後 8 力月の現在, 両下肢の腱反射先進証残存子るが, 歩行障書, 知筧障害 ともに著明に改善した。

\section{4. 手術成績}

手術成績は Fig. 13 のごとくである。O印は術前の神 経症状，一印注術後の神経症状である，神経根症状，春

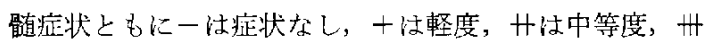
忙高度の障害を表す。術後の観察期間はむだ短く, 昭和 54 年 12 月末現在で最長 1 年 11 力月, 最短 5 力月であるが,

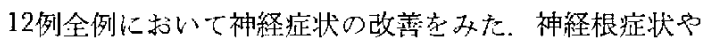

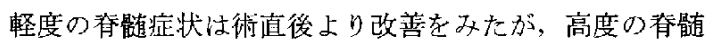
症状恃回復が遅孔る傾向を示した，特に腱反射方進扝上 び足䦎代注，筋力低ドや知覚障害が正常に近いほど回復 してもまだ残存する例が多かった。
奉椎管狭小率と脊髄症状の改善の程度をみると, Table

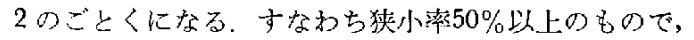

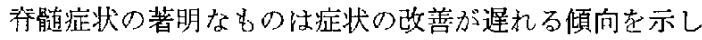
た.

骨化巣摘出後の前方固定部位は，3椎体を固定したも の 1 例, 4 椎休固定 9 例， 5 椎体固定 2 例であった. 上 限のレベルは $\mathrm{C}_{2}$ 下縁，下限泩 $\mathrm{T}_{1}$ 上縁であった(Table 3).

\section{5. 手技上の問題}

著者らが経験した手技上の問題点は Table 4 のごとく である，骨化巣一部残存の3 例はいずれも骨化果の側方 部分が残存したものであった. 1 例は再手術を行い摘出 した， 1 例は神経症状が著しく改善したので再手術究行 わず経過を双ている，1例はきわめて軽度の残存であっ た．移植骨骨折 2 例俚，腸骨の骨皮翼が側方にくるよう に挿入した例で，捚入時移植骨が骨溝より厚かったた め，移植骨の側方の骨皮質を削ったためと思われた。こ れら 2 つトラブルはいずれむ初期の例に経験したもの 


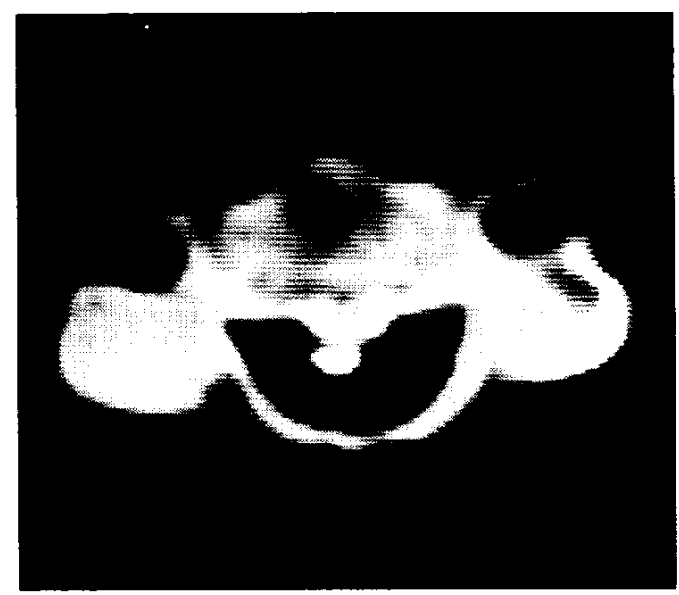

a

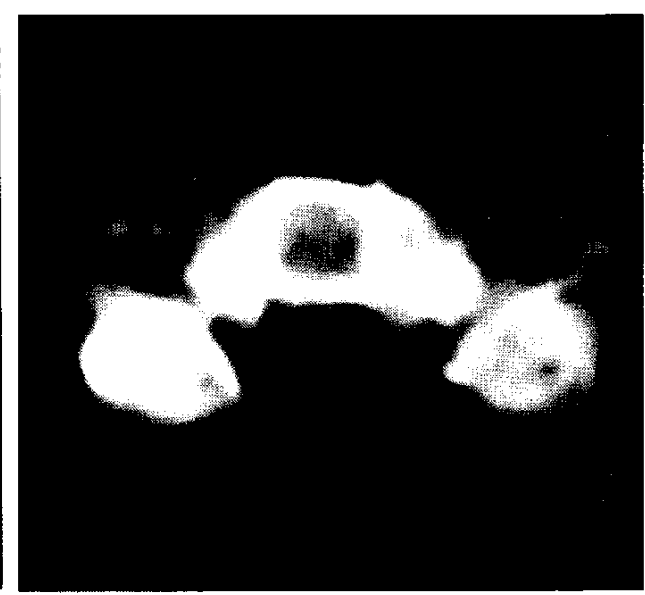

b

Fig. 8 Case 6

a: Spinal CT scan demonstrates the ossified ligament at $\mathrm{C}_{3}$. $\mathrm{b}$ : One year after the operation.

で，乙れ以後は経験していない，硬膜欠損 3 例は，骨化 巣が硬膜に密着していたもので硬膜ごと摘出したたいに 生した。少さな損は $0.7 \times 1.2 \mathrm{~cm}$ ，大きな久損は 1.0 $\times 3.6 \mathrm{~cm}$ に及んだ，2例は》毛膜に小孔加施き，彶中 髄液の漏出圭みたが，いずれも gelform の補充で問题は

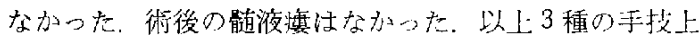
の問題があったが，こ和らのトラブルにより神経济状の 悪化した例はなかった

\section{$\mathbb{N}$ 考按}

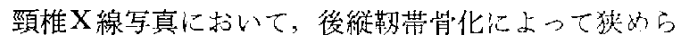

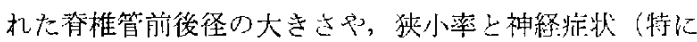
金髄症状〉の発現扝よぴ程度については，寸でに報钅がみ ら水万が，狭小率の程度や残存才者椎管前後径の大き さと替䯠症状の程度とは必ずしも羿行しないという報告 が多い(13)18283．著者らの前方国定䘮行った12例について

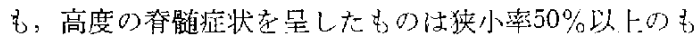

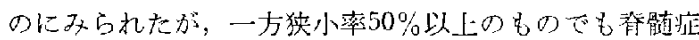
状が比較的軽度のもの恓あったり，また50\%以下でも川 等度の脊髄症状在呈したものがあったことは興味深い．

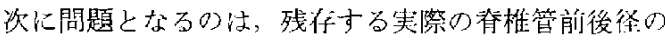

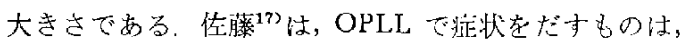
その個人がもつ本来の宜椎管前後径 anterior-posterior diameter 加狭い人に発症しや寸く，骨化部位での䒠際の 前後径 thecoperiosteal diameter (志たは absolute anterior-posterior diameter) が，頸椎単純撮影に扝ける計測 で $9 \mathrm{~mm}$ 以下になると种経症状を発すると述べている。
问しく中西 ${ }^{13)}$ は，頸椎断庴写真汒よる测定で，神経症状 呈した症例の平均瓷惟前後径 absolutc diameter が7.8 $\pm 2.7 \mathrm{~mm}$ であると報㸃し; 柳 ${ }^{28)}$ 注，神経症状を呈した 群の天礼が平均 $8.2 \pm 2.0 \mathrm{~mm}$, 神程症状のなかわ群の それは $12.0 \pm 1.8 \mathrm{~mm}$ と報告している。著者らの頸椎断 層写真に拉け石狄小化された前後径 absolute anteriorposterior diameter

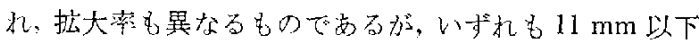
であった。亦なわら残存寸万春椎管前得径の大きさは症 状発現に関与する因子であるといえる。しかしながら， 前後径の大きさは狭小率と同様に，骮症状の程度とは 必ずしも平行しているとはいえ尔加た。この理由とし てはいくつかの点が举げら机る。つまり春髄症状の発現 や程废法，脊椎管前後径の大ささや狭小率の他心，骨化

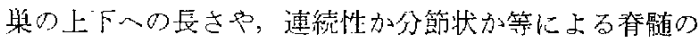

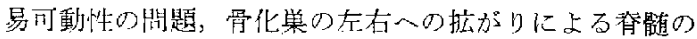
偏位，また活济䯣の血流動態の問題などが関与寸る上思 放る。

最近 OPLLに関する spinal CT scan の報告がふえつ

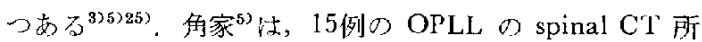
見在検討し， spinal CT 情化栄と背椎管の関保，骨化 紧の横断面の形状や左右への広がり等在明膫に把握寸る ことができ，手術術式の選招や娭討にきわめて有用であ ったと報告している，Yamamoto ${ }^{25}$ 注，21例の OPLL $の$ spinal CT 可見老换討し，神経症状を呈した18例に招い て，骨化紧の形態と神経症状のあらわれ方に関連があっ たと報告している，著者らの経験でも，OPLLの spinal 


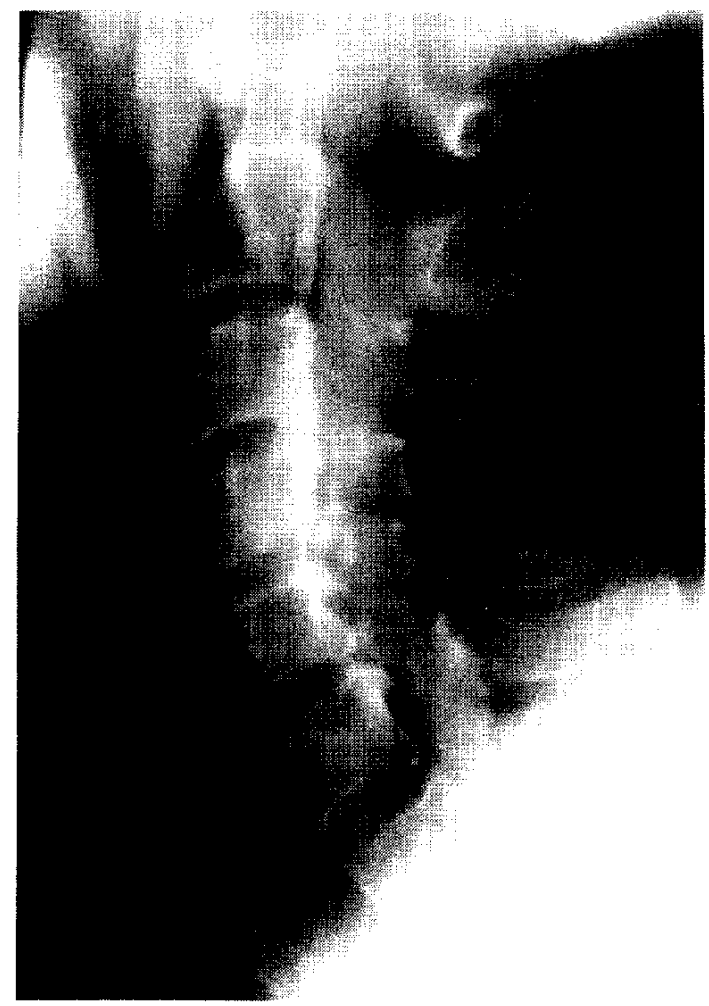

a

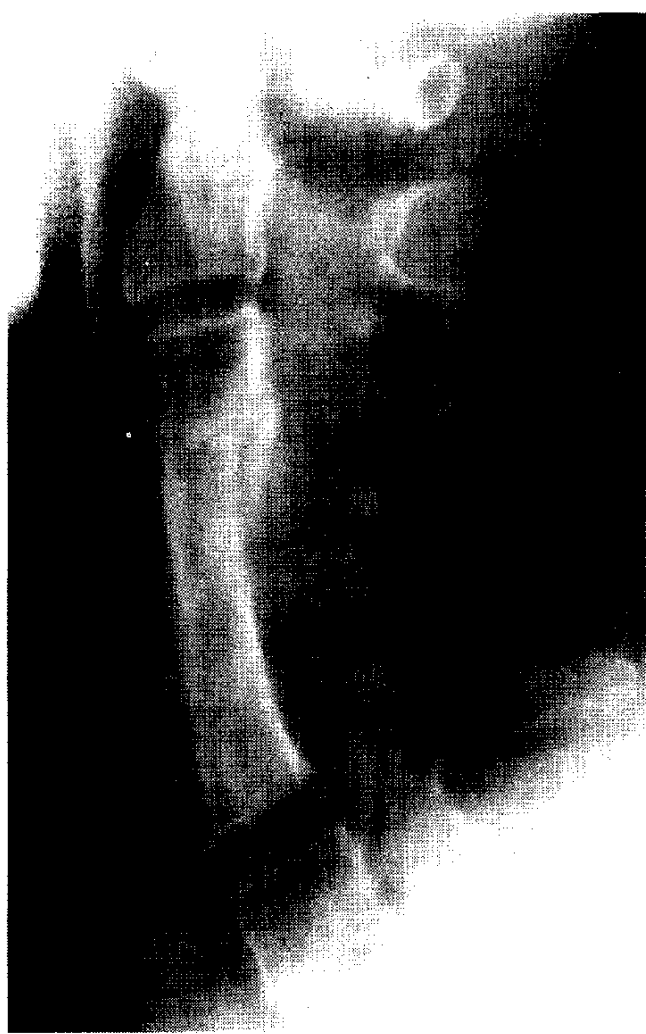

b

Fig. 9 Case 4

a: Preoperative tomogram showing the ossificd ligament at $\mathrm{C}_{4}-\mathrm{C}_{6}$.

b: Ossified ligament was removed and anterior fusion was carried out from $\mathrm{C}_{3}-\mathrm{C}_{6}$.

CT は多くの情報をもたらし，術前・術後の検討に spinal CT は必須であった，特に衔後のCT では，OPLL 走完全に摘出した加どうか，椎体の切除範囲や移植骨の 位置，大きさが適切であったかどうか度知るのにきわめ て有用であった。ただ spinal CT たは，下位頸椎になる 注どスライスを椎体に平行に甽ることが難しく，またり インドゥ幅变えることによって变化策の大きさむ変化 するなどの闍題があり，現状では爰密に条化を一定化す ること沁必ずしも容易てはなくこれらの点の解決が望 ま机る。

OPLL の外科的治療について梳くの報告があるが， 従来は主しして laminectomy に上名後方除任が行かれ てきた。長鳥 ${ }^{11123}$ は，10例の OPLL に対して広範な laminectomy $と$ facetectomy を行い, follow up のできた 9 例の5ち, excellent 6 例, improved 3 例 已好成績を報 告している。桐田 ${ }^{79}$ は, OPLL 155例に後方除止在行い,

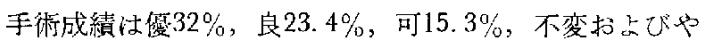

や有効 $13.1 \%$ で，全体の満足度は70\%と報告している. 手術徣の症状の改善の度合法，術前の神経症状の程度， 発症から手術までの期間などいらいろな困子により左右 されるが， laminectomyによる後方除压に上って神経症 状，特に沓髄症状は汃なりの症例で改善が期待されると いえる。長島は laminectomy+facetectomy $の$ 有用性を 強諰しているが，著者らの释験です同㴍の意見である。

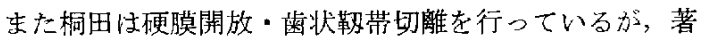
者らは原則として硬膜は開かない方針をとっている。 1977年まで, 我々も約50例の OPLL に対して lamine-

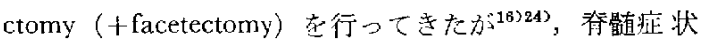
に対しては汪全例で改善がみられているが，神経根症 状に対しては facetectomy 在併せ行っても必ずし女䓑足 导べきものとはいえなかった。ささに OPLL は毎年骨

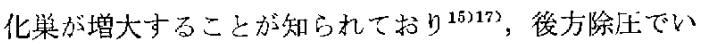
ったんは症状の改善をみた患者が，数年〜十数年後に再 び悪化している例に遭遇するにつれ，上り根治的な治療 


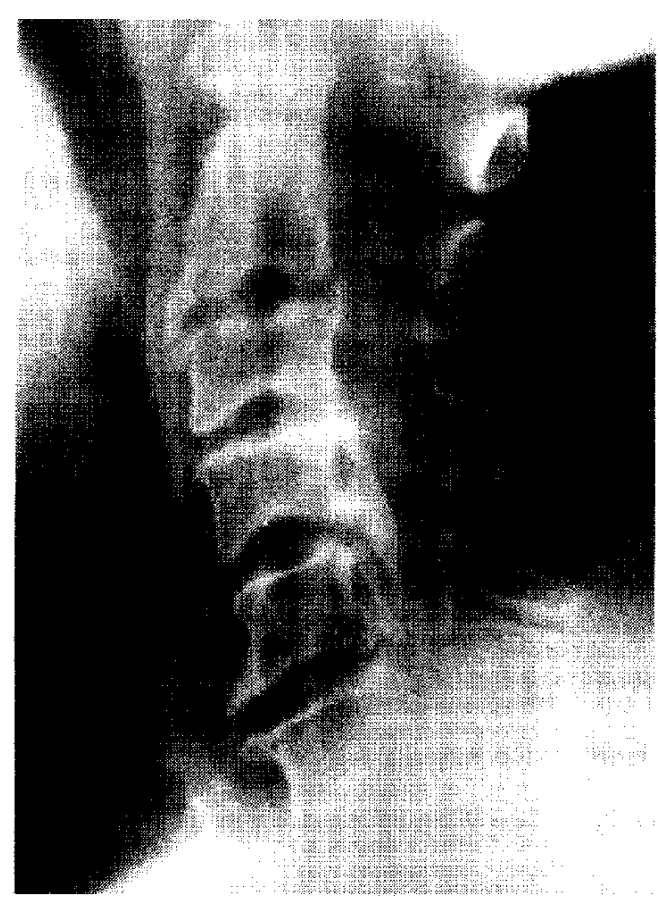

a

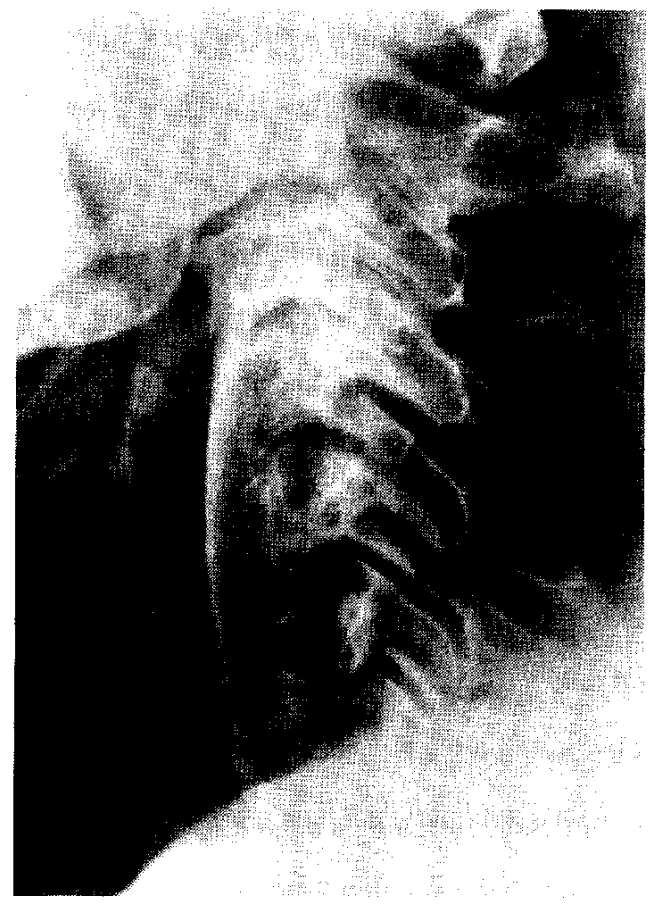

b

Fig. 10 Case 3

a: Preoperative tomogram showing the ossified ligament at $\mathrm{C}_{4}-\mathrm{C}_{6}$.

$\mathrm{b}$ : Three months after the operation. Ossificd ligament was romoved and anterior fusion was pcrformed from $\mathrm{C}_{3}-\mathrm{C}_{7}$.
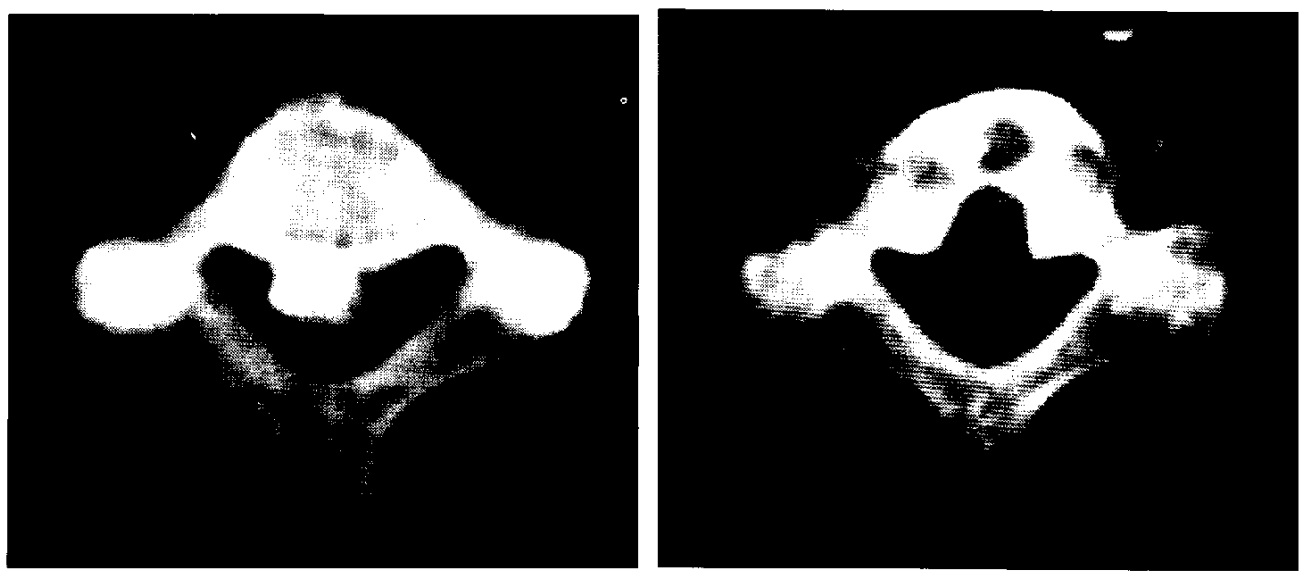

a

b

Fig. 11 Case 3

a: Spinal CT scan demonstrates the ossified ligament at $\mathrm{C}_{4}$.

$b$ : Three months after the operation.

法の確立が望をれるよらになった。つまり，前方上り到 達して骨化宩を摘出しようといら試みがなされてきたの である。
1970年代の初めから，整形外科領域ではすでに前方除 压の試みがなされて扝り, 近年手術手技の進歩, 手術器 具の改良，マイクロスコープの使用などにより症例も増 


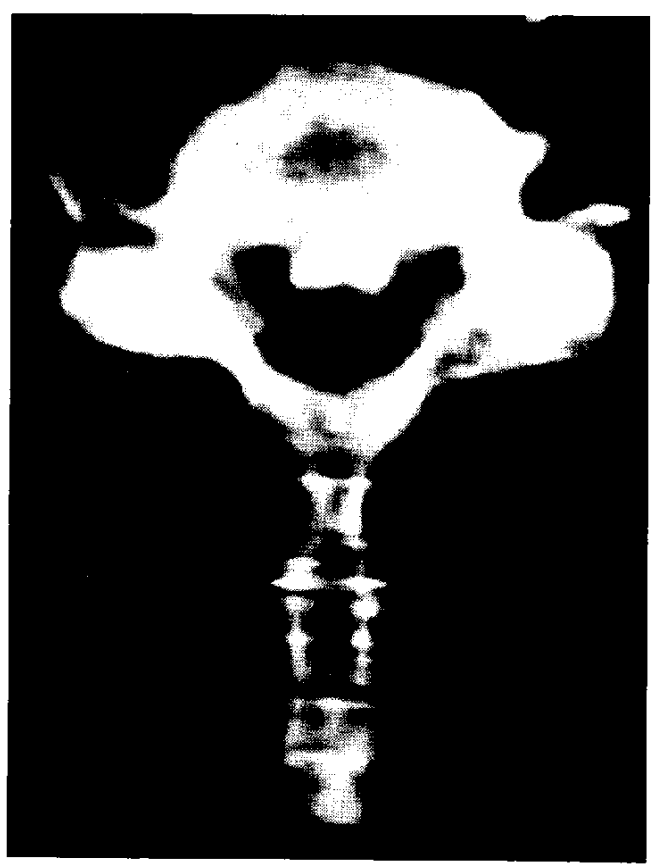

a

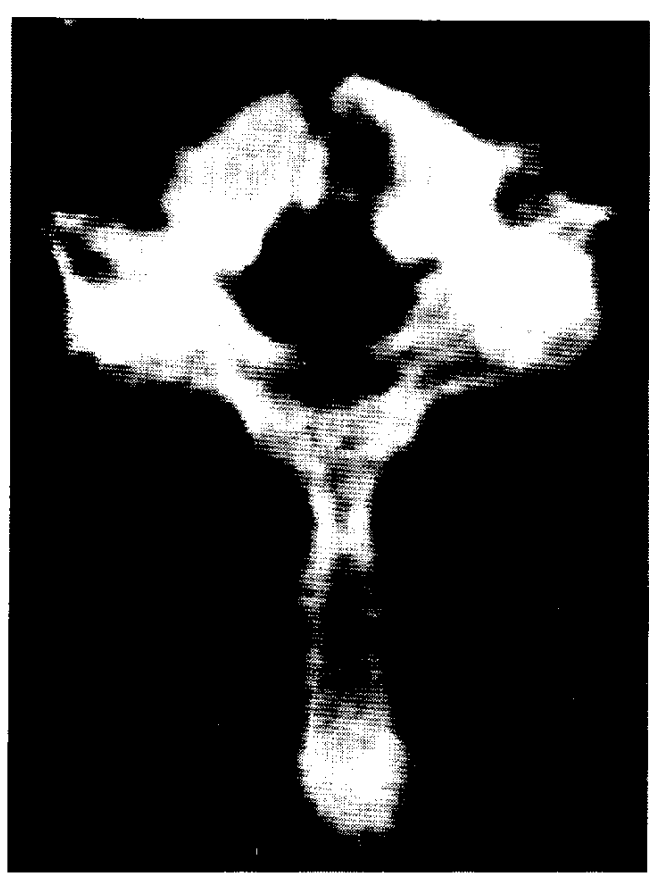

b

Fig. 12 Case 11

a: Spinal CT scan demonstrates the ossified ligament at $\mathrm{C}_{7}$. b: Three months after the operation.

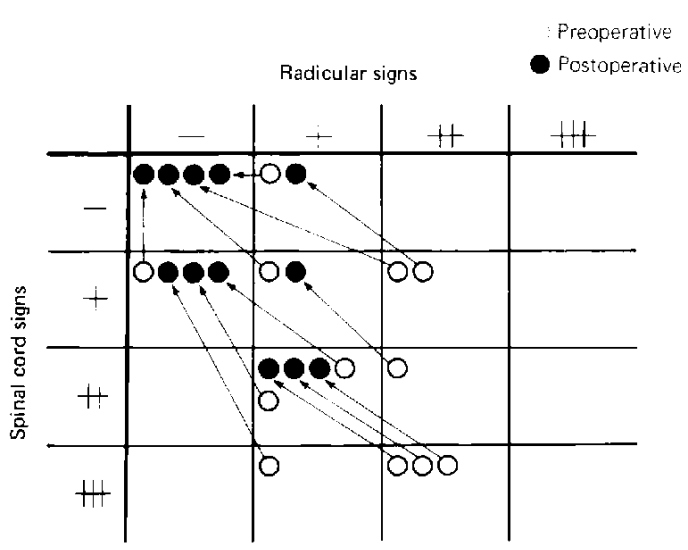

Fig. 13 Operative results.

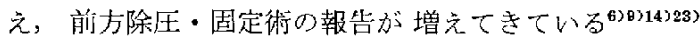
27). 真錭”注，8例の前方除圧手術在行っているが，1 例に根症状の残存をみた他恃す心゙て神経症状の改善をみ ており，渡部 ${ }^{23)}$ 女 7 例の前方除压で神経症状の悪化は 1 例も加ていないなどの報告があり，その手術成績は良好 である。我々の12例で女，前方除圧によって神経症状の 悪化をみたものはなかった。これらのことから前方除正 術沈まだ楚史も浅く，follow up 期間も短く，症例も少
Table 2 Improvement of spinal cord signs

\begin{tabular}{|c|c|c|}
\hline & Prcoperative & Postoperative \\
\hline \multirow{6}{*}{ More than $50 \%$} & 世 & $\longrightarrow H$ \\
\hline & + & $\longrightarrow \quad-$ \\
\hline & 世 & $\longrightarrow+$ \\
\hline & H & $\longrightarrow+$ \\
\hline & + & $\longrightarrow \quad \pm$ \\
\hline & $H$ & $\longrightarrow \quad+$ \\
\hline \multirow{6}{*}{ Less than $50 \%$} & + & $\longrightarrow-$ \\
\hline & + & $\longrightarrow \quad-$ \\
\hline & $H$ & $\longrightarrow \quad+$ \\
\hline & $H$ & $\longrightarrow+$ \\
\hline & + & $\longrightarrow \quad-$ \\
\hline & H & $\longrightarrow \div$ \\
\hline
\end{tabular}

ないが，きわわて有望な治療法といえると思われる，前 方除压術による症状改善の理由の1つは，骨化紧を摘出 することに上り，湊䯣や神経根を確実に前方，すなわち 本来のある心きき位置へもどすことができるからであり， 一方後方除圧は，春咀や神経根が後方一䢠げるが，同时 に伸展あるいは部分的に屈曲を伴らような場合があるた め，ときには症状の改善がみられなかったり，あるいは 
Table 3 Fused levels

\begin{tabular}{ccc}
\hline & Fused levels & Cases \\
\hline 3 bodies & $\mathrm{C}_{5}-\mathrm{C}_{7}$ & 1 \\
\hline \multirow{3}{*}{4 bodies } & $\mathrm{C}_{2}-\mathrm{C}_{5}$ & \\
& $\mathrm{C}_{5}-\mathrm{C}_{6}$ & 9 \\
& $\mathrm{C}_{5}-\mathrm{C}_{7}$ & \\
& $\mathrm{C}_{5}-\mathrm{Th}_{1}$ & \\
\hline & $\mathrm{C}_{3}-\mathrm{C}_{7}$ & 2 \\
\hline
\end{tabular}

悪化が办られるのではないかと思われる。

前方除压固定術は，原則としては椎体正中部に必要な 長さと幅（約 $1.2 \sim 1.5 \mathrm{~cm}$ ) の骨溝作り，骨化果を摘 出し，適切な大きさの移植骨を挿入することである。し かしながら，そこにいくつかの pitfalls がありらるので 細心の注意が必要である。まず第 1 亿椎体正中部の削り 方であるが，骨化巣の側方を上り残さないように前面よ りる後面老幅広く削ることが大切である，我々の初期の 3 例では，十分に骨化巣を摘出したと思ったものでも， 很後のCTで骨化果の側方がわずかに残存していた，第 2 む骨化单を掂出する際の問題である。骨化巣法, air drill でできるだけ薄く1〜2mm の厚さにして, microrongeur で piece by piece に摘出するのであるが, その際 に骨化策の一端乥椎体の一部につけたまま摘出する方が 摘出しやすいことである，骨化巣の周囲を削りとって骨

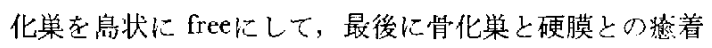
在はがしながら摘出する方法性, microrongeur で摘出す るたびに，骨化巣の他端が動いて春髄を損賃する恐れが あるので注意せねばならない，第 3 は硬膜とり瘾着の問 題である，骨化巣と硬膜との癒着はそれほど著明でなく 容易に剝膟できる場合と，癒着が著鹏であたか子硬膜自 体が骨化したと思われる上うな例むあった。骨化策が硬 膜に密着しているときには，摘出の際にどらしても便膜 に久損が生じる。その祭にクモ膜をできるだけ椇傷しな い注意が肝心である，我々の経験した最大の硬膜欠損仕 $1.0 \times 3.5 \mathrm{~cm}$ であったが， gelform 在あてることで特に 問題はなかった。しかし今後は，大きな硬膜の欠椇には

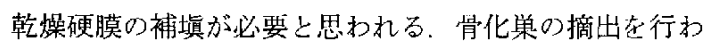
す，椎体正中部の东を切除して骨化栄を前方に浮上させ

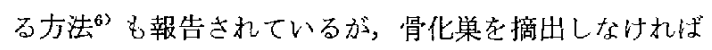
十分な除圧効果は得られず，いずれ东を骨化柴は増大し てくるので，我々はできるだけ骨化巣の全摘出をす心゙き であると考えている，第 4 は移植骨の問題である，移植 骨は腸骨より採取するが，術後の腸骨の変形を避けるた
Table 4 Technical problems

$\begin{array}{ll}\text { Residual OPLL } & 3 \text { Cases } \\ \text { Dural defect } & 3 \\ \text { Fracture of grafted bone } & 2\end{array}$

め，約 $1 \mathrm{~cm}$ の厚さの骨棱部分を腸骨へもどす，移植骨 片は，初期には骨皮澌が左右側面八くるように㧴大した が，固定が多椎体に及ぶときには，移植骨片が弯曲してい るため，側面の骨皮質を削って真直ぐな移植骨にせねば ならず，ために強勒さを失って，2例に術後の骨折をみ た. 以後は骨皮質が前後にくるよらに挿入している。虫 た移植骨が前方や後方にずれない上らに移植骨の上下の

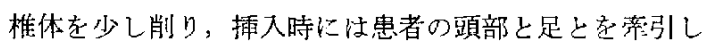
て插入する. 適切な形心長い移植骨をきらんと椎体切除 部に挿入する手技は，骨化策摘出に劣らず大切である。

次に前方除圧術の適応について述べると，少数例では

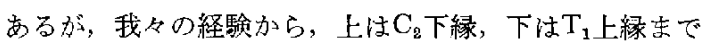
のものであれば，ほとんどの症例は前方除圧の適応にな ると思われる。手術の適応については，狭小率40\%以上 のものは手術の適応であるといら報告”るあるが，狭小 率が小さなものは術後の症状の改善が良かった点考考光 ると，数值をもって手術適応を決めることななかな加難 しい問題である。結局, 個々の例に拈いて狭小率, 脊椎 管前後径, 神経症状の有無・程度等を考慮して総合的に 判断しなければならないが，むっとも重要なのはやはり 神経症状の有無であるう。少なくとも何らかの神経怔状

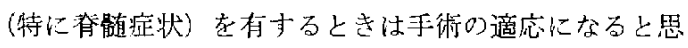
わ扎る，我々の経験した前方除圧術による最多固定椎体 は5椎体であったが, $8 \sim 9 \mathrm{~cm}$ の長さの強靶な移植骨さ え採取できれ沿 6 椎体固定む可能と思われる。しかしな がら高度な春䯠症状を有し, manometric Queckenstedt's test でブロックが著明かつ myelographyにて造影剂のブ

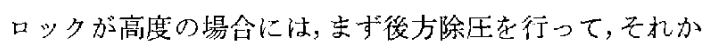

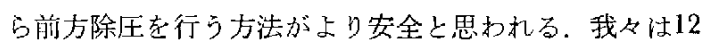
例中 4 例にこの方法亲用い良い結果交得た，ブロックが 著明な場合のこの“二段階方式”は，我々汢すでに cer一 vical spondylosisで用いて㧍り ${ }^{22}$ ，良好な成績を残して いる。

前方除厌術の残る問題点は, 胸椎レベルのOPLL む前 方からの摘出が可能かどうかという点である。限局した 胸椎椎間板へルニアや愁椎カリエスに対しては, 開胸し て前方から到達したり，束たは䐧膜在圧排して後側加 ら到達する方法の報告はみられるが゙1日，多椎体に及方 胸椎 OPLL の削方除压の報告はない. しかし最近, 我々 は $\mathrm{T}_{5}-\mathrm{T}_{6}$ の资㵦動静脈奇形に対して, nidus が尙㵦の前 
方に位置していたたかに，開胸して $\mathrm{T}_{5} ， \mathrm{~T}_{\mathrm{a}}$ の椎体の前 側力を削って到達し, nidus 摘出に成功した 1 例を経験し たので，限局性の胸椎 OPLLに対しては，将来掂出が 可能になると思われる。

後縦勒带骨化の発生機序につWては，剖検例や生検材

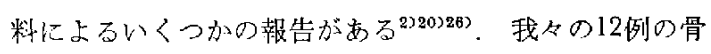
化紧摘出の経験から興味あると思われた点は，X線フィ ルムには骨化像として写っていない部分においても，骨 化单の続きとして靶帯の著明な肥厚がみられた例があっ たことで女る，肥厚した靬蒂内には血管結合織の増生が みられ，摘出の際に鞄帯からの出向があった。これらの 肥厚加らがて骨化していくものと思われる。このこと はすでに山浦 ${ }^{263}$ が報告しているが，興味のある点で我

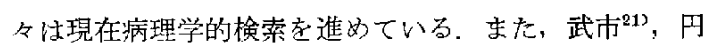
尾 ${ }^{10)}$ が報告しているごとく，硬膜自体も骨化していると 思われた例名 3 例あった。これらの症例では，骨化巣の 摘出による硬膜欠損法避けられない問題である。これら についても病理学的検封を進るている.

\section{V 結 語}

1. 12例の到椎 OPLL 症例に対して, 前方到達法に上 って骨化单を摘出し，前方除压周定学行った。

2. 術後は全例に神経症状の改善老みた. 脊椎管前後 径狭小率の大さいもの (50\%以上) は, 春髄症状の改善 に時閒要した。

3. 前力より到達可能なレベルは，上は $\mathrm{C}_{2}$ 下緑，下 は $\mathrm{T}_{1}$ 上粶までであった。最多固定椎体は 5 椎体であっ た.

4. 手技上の注意として次の 2 点が重要であった。 (1) 骨化巣齐摘出寸る際には，椎体後面の側方を広く削り， 骨化巣を-分に摘出することが大切である。(2)移椬骨 は，十分な強度の骨片を使用寸ることが必要である。

本論文の要旨は，第38回日本脳神経外科学会総会(1979 年 10 月，東京) 女第 5 回アジア大洋州莤神释外科学会 (1979年11月，マニラ)にて発表した。 Spinal CT scan の撮影汇御協力いただいた北海道大学放射線科宫圾和 男先生および北海道大学脑神経外科井唡豊渗先生に哚 謝する。

\section{文献}

1) Benjamin, M. V. \& Ransohoff, J.: Thoracic disc disease. pp 435-442, In Rothman, R. H. \& Simeone, F. K. (eds): The Spine, I, W. B. Saunders Company, Philadelphia, 1975
2) 占屋光太郎, 山浦伊梁吉, 高山勝：頸椎後 縦勒带骨化の 1 剖桱例。日整会誌42：1131-1138， 1968

3) Hyman, R. A., Marten, C. W., Liebeskind, A. L., Naidich, J. B. \& Stein, H. L.: Computed tomography in ossification of the posterior longitudinal ligament. Neuroradiology 13: 227-228, 1977

4）伊藤輝史，会田敏光，都留美都雄，橋本正人， 金田清志：胸髄動静脈奇形の開胸前方到達法に よる治療経験。第14回日本パラプレジア医学会 抄録集, 1979, pp 31

5）角家 晊, 中村 勉, 大橋雅広, 広瀬源二郎, 多田 明：CＴ像上りみた後縦勒帯骨化症の検 封，篦外 $7: 63-70 ， 1979$

6）上小鶴正弘, 山浦伊装吉, 藤井紘三, 四宮謙

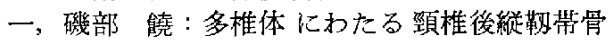
化に対子る前方除圧術の検討. 臨整外 $12 ： 416$ 424,1977

7) 桐田主人, 宮崎和躬, 林 達雄, 野坂健次郎, 山村 絠，玉木茂行，長嵨哲夫：頙椎症 - 後积 靬带骨化症に対与当後方除在について，手術30： $287-302,1976$

8)桐田良人：後緃勒帯骨化症江対与る後方除压 法一特に広範囲局時除压式椎乃切除術について 一。整形外科 $30: 45-49,1979$

9) Manabe, S. \& Nomura, S.: Anterior decompression for ossification of the posterior longitudinal ligament of the cervical spine. Neurol Surg 5: 1253-1259, 1977

10) 円尾宗司，片网 治，水野耕作：硬膜 $の$ 骨化 老伴与頸椎後縦靸带骨化症の一剖検例，日整会 誌50:37-43, 1976

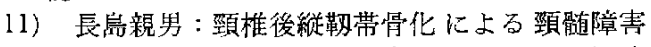
の手術法の研究一ならびに本骨化とその近縁冼 患上の関連についての孝察。訤神経24：13-25, 1972

12）長島親男：頚椎後縦鞄带骨化による頸髄障害 の手術的療法. 手術26：211-222，1972

13）中西孝雄, 豊倉鹿夫, 萬年”徹, 坂口亮, 津山直一：頚椎後秤鞋带骨化症一その臨床所兒 とX線像について一. 臨床神释 7 : 607-618, 1967

14) 酒包 崇: 频椎後縌勒带骨化症に拉ける前方 除压手術について。手術30：281-285，1976

15）佐々木正：頚椎後緃靬带骨化症 0 長期経過観 察一骨化増大定中心として一。災害医学21：853 $-861,1978$

16) Sato, M., Mitsumori, K., Nakagawa, Y., Tsuru, M. \& Y ADA, K.:Cervical radiculomyelopathy due to an ossified posterior longitudinal ligament. Excerpta Medica 293: 111, 1973

17）作藤正治，都留美都雄，矢出賢三：頸椎後縱

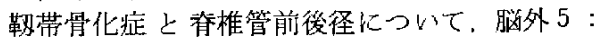
$511-517,1977$

18）柴崎 浩, 承松啓爾 : 頸椎変性疾患群一とく 


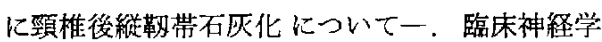
$8: 22-29,1968$

19) Simeone, F. A. \& Rashbaum, R.: Transthoracic disc excision. pp 323-333, In Schmidek, H. H. \& Sweet, W. H. (eds); Current techniques in operative neurosurgery, Grune \& Stratton, New York, 1977

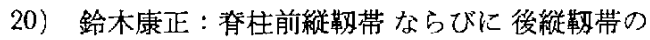
解剖学的研究. 特にその微細構造と骨化病態に ついて．日整会誌 46：179-195，1972

21) 武市早苗, 高橋正倫, 井形高明：硬膜骨化を 伴った頸椎後縦勒帯骨化症の 2 剖検例。臨整外 $9: 179-185,1974$

22）都留美都雄, 阿部 弘 : Cervical spondylosis, Disc の手術，譄外 $3: 15-20 ， 1975$

23）渡部恒夫, 并上駿一, 辻陽雄, 宮坂斉, 伊藤達雄：颈椎後縦靭带骨化症にたいする 前方
除生法。手術32：59-67，1978

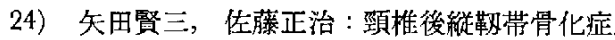
Medicina 11 : 1436-1439, 1974

25) Yamamoto, I., Kageyama, N., Nakamura, K. \& Takainashi, T.: Computed tomography in ossification of the posterior longitudinal ligament in the cervical spine. Surg Neurol 12: 414-418, 1979

26）山浦伊婆吉：頸椎後縋勒帯骨化症 $の$ 発生進展 機序. 災害医学18：651-662，1975

27) 山浦伊装吉, 磯部饒, 藤井紜三, 斉藤 俊, 上小鶴正弘，四宫謙一，古尾光太郎：頸椎後能 靱带骨化症に招ける観血的治療法 除圧法を中心として一, 整形外科 $27: 87-95$, 1976

28）柳務：頸椎後縱鞋带骨化 $の$ 臨床とレ線所 見に関する研究．脳神経22：909-921，1970 